\title{
Mariniflexile gromovii gen. nov., sp. nov., a gliding bacterium isolated from the sea urchin Strongylocentrotus intermedius
}

\begin{abstract}
Correspondence
Olga I. Nedashkovskaya

olganedashkovska@piboc.dvo.ru

or

olganedashkovska@yahoo.com
\end{abstract}

\author{
Olga I. Nedashkovskaya, ${ }^{1}$ Seung Bum Kim, ${ }^{2}$ Jangryul Kwak, ${ }^{3}$ \\ Valery V. Mikhailov ${ }^{1}$ and Kyung Sook $\mathrm{Bae}^{3}$ \\ ${ }^{1}$ Pacific Institute of Bioorganic Chemistry of the Far-Eastern Branch of the Russian Academy \\ 2Department of Microbiology, School of Bioscience and Biotechnology, Chungnam National \\ University, 220 Gung-dong, Yusong, Daejon 305-764, Republic of Korea \\ ${ }^{3}$ Korea Research Institute of Bioscience and Biotechnology, 52 Oun-dong, Yusong, \\ Daejon 305-333, Republic of Korea
}

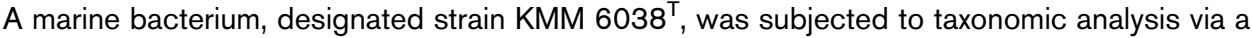
polyphasic approach. Cells of the strain were heterotrophic, orange-pigmented, Gram-negative and motile by means of gliding. $16 \mathrm{~S}$ rRNA gene sequence analysis indicated that strain $\mathrm{KMM}^{-6038^{\top}}$ was closely related to the type species of the genera Algibacter and Yeosuana, members of the family Flavobacteriaceae, with sequence similarities of 93.8 and $93.6 \%$ to the respective type strains. However, several chemotaxonomic and phenotypic characteristics, such as the cellular fatty acid profile (iso- $C_{15: 0}$, anteiso- $C_{15: 0}$, iso- $C_{15: 1}, C_{15: 0}, C_{15: 1} \omega 6 c$, iso- $C_{15: 0} 3-O H$ and iso- $C_{17: 0}$ $3-\mathrm{OH})$ and the low $\mathrm{G}+\mathrm{C}$ content of the DNA (35.7 mol\%), indicated that the strain should be separated from these two genera. From the results of phenotypic, genotypic, chemotaxonomic and phylogenetic analyses, the bacterium should be classified as representing a novel genus and species, for which the name Mariniflexile gromovii gen. nov., sp. nov. is proposed. The type strain

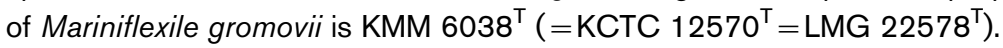

In the course of a study of a microbial population of the sea urchin Strongylocentrotus intermedius, a common echinoderm from the north-western Pacific Ocean, a heterotrophic, Gram-negative, gliding and orange-pigmented marine bacterium was recovered. Based on a polyphasic study of the isolate, designated $\mathrm{KMM} 6038^{\mathrm{T}}$, which included phylogenetic, genotypic, chemotaxonomic and phenotypic approaches, the erection of a new genus within the family Flavobacteriaceae is proposed.

Strain KMM $6038^{\mathrm{T}}$ was isolated from the sea urchin $S$. intermedius inhabiting Troitsa Bay, Gulf of Peter the Great, East Sea (also known as the Sea of Japan), in September 2002. For strain isolation, $0 \cdot 1 \mathrm{ml}$ aliquots of homogenates of sea urchin tissues were transferred onto plates of marine agar 2216 (Difco). After primary isolation and purification, strains were cultivated at $28{ }^{\circ} \mathrm{C}$ on the same medium and stored at $-80^{\circ} \mathrm{C}$ in marine broth (Difco) supplemented with $20 \%(\mathrm{v} / \mathrm{v})$ glycerol.

Genomic DNA extraction, PCR and sequencing of the $16 \mathrm{~S}$ rRNA gene followed the procedures given by Han et al.

The GenBank/EMBL/DDBJ accession number for the 16S rRNA gene sequence of Mariniflexile gromovii KMM $6038^{\top}$ is D0312294.
(2003). The sequences obtained were aligned with those of representative members of selected genera belonging to the family Flavobacteriaceae by using PHYDIT version 3.2 (http:// plaza.snu.ac.kr/ jchun/phydit/). Phylogenetic trees were inferred using suitable programs of the PHYLIP package (Felsenstein, 1993). Phylogenetic distances were calculated using the Kimura two-parameter model (Kimura, 1980) and trees were constructed on the basis of the neighbour-joining (Saitou \& Nei, 1987), least-squares (Fitch \& Margoliash, 1967) and maximum-likelihood (Felsenstein, 1993) algorithms. Bootstrap analysis was performed with 1000 resampled datasets by using the SEQBOOT and CONSENSE programs of the PHYLIP package.

Phylogenetic analysis of the almost-complete 16S rRNA gene sequence of strain KMM $6038^{\mathrm{T}}$ (1378 nt) revealed that the strain formed a distinct lineage within the family Flavobacteriaceae (Fig. 1). The strain was clustered with Yuosuana aromativorans $\mathrm{GW} 1-1^{\mathrm{T}}$ in the neighbour-joining tree shown, a relationship that was also supported by the maximumlikelihood tree. However, the level of bootstrap support was only $52 \%$, indicating that the topology of tree was not stable. Strain KMM $6038^{\mathrm{T}}$ showed $16 \mathrm{~S}$ rRNA gene sequence similarities of 93.6 and $93.8 \%$ to Y. aromativorans $\mathrm{GW} 1-1^{\mathrm{T}}$ 


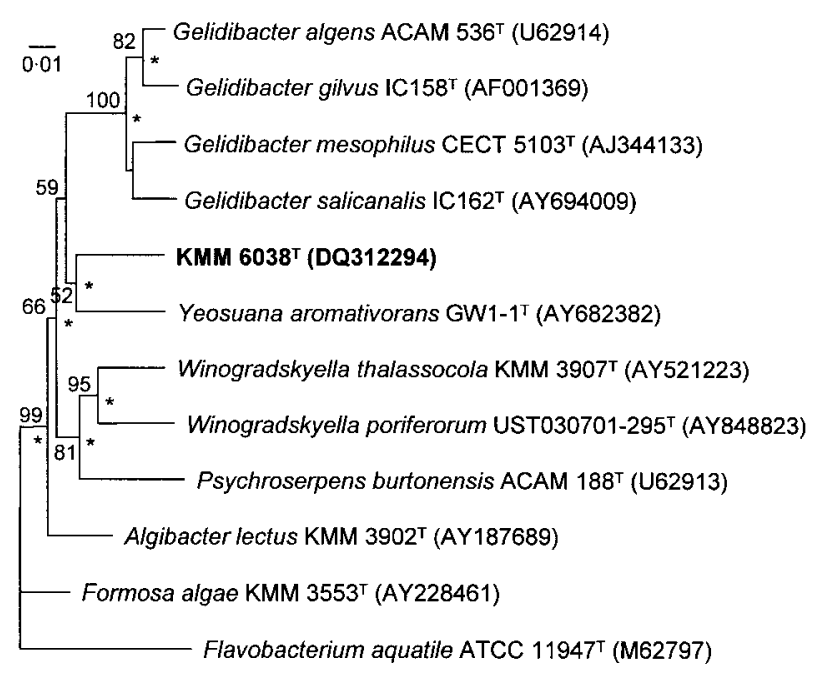

Fig. 1. Phylogenetic tree based on the 16S rRNA gene sequences of strain $\mathrm{KMM} 6038^{\top}$ and representative members of the family Flavobacteriaceae, constructed by the neighbourjoining method. Asterisks indicate branches that were also recovered by using the maximum-likelihood algorithm. Numbers at nodes indicate bootstrap values (\%) from 1000 resamplings. Bar, 0.01 substitutions per nucleotide position.

and Algibacter lectus KMM $3902^{\mathrm{T}}$, respectively, and less than $93.1 \%$ to other members of the family Flavobacteriaceae. A. lectus KMM $3902^{\mathrm{T}}$ shared higher sequence similarity with KMM $6038^{\mathrm{T}}$ than $Y$. aromativorans $\mathrm{GW} 1-1^{\mathrm{T}}$ but formed a separate phylogenetic cluster, given that A. lectus KMM $3902^{\mathrm{T}}$ also shared high sequence similarities with other strains such as Formosa algae KMM $3553^{\mathrm{T}}(95 \cdot 1 \%)$. Y. aromativorans $\mathrm{GW} 1-1^{\mathrm{T}}$ shared $93.6 \%$ sequence similarity with Gelidibacter algens ACAM $536^{\mathrm{T}}$. Therefore, it is evident from the phylogenetic analysis that KMM $6038^{\mathrm{T}}$ is not the closest neighbour of either A. lectus or Y. aromativorans.

DNA was isolated following the method of Marmur (1961) and the $\mathrm{G}+\mathrm{C}$ content was determined by the thermal denaturation method (Marmur \& Doty, 1962). The DNA $\mathrm{G}+\mathrm{C}$ content of strain $\mathrm{KMM} 6038^{\mathrm{T}}$ was $35 \cdot 7 \mathrm{~mol} \%$.

Analysis of fatty acid methyl esters was carried out according to the standard protocol of the Microbial Identification System (Microbial ID), except that marine agar 2216 was used to obtain cell biomass. The dominant fatty acids are detailed in the species description and in Table 1. Isoprenoid quinones were extracted from lyophilized cells and analysed as described previously (Nedashkovskaya et al., 2004); the major respiratory quinone was MK-6. These results are consistent with those obtained previously for members of the family Flavobacteriaceae (Bernardet et al., 2002).

Phenotypic analysis was performed by using our previously described methods (Nedashkovskaya et al., 2004).
Cells of strain KMM $6038^{\mathrm{T}}$ were Gram-negative, chemoorganotrophic and motile by means of gliding. The isolate did not require $\mathrm{Na}^{+}$ions or seawater for growth, which occurred in media that contained $0-6 \% \mathrm{NaCl}$, with optimum growth at $1-2 \%$. The maximum growth temperature of strain KMM $6038^{\mathrm{T}}$ was $37^{\circ} \mathrm{C}$, with optimum growth occurring at $23-25^{\circ} \mathrm{C}$. The $\mathrm{pH}$ range for growth was $5 \cdot 5-$ $10 \cdot 0$, with optimum growth occurring between $\mathrm{pH} 7 \cdot 5$ and $8 \cdot 3$. Other physiological and biochemical characteristics of the strain are listed in the species description and in Table 2. Strain KMM $6038^{\mathrm{T}}$ has several characteristics that help to differentiate it from its nearest neighbours, Y. aromativorans and A. lectus (Table 2). Phenotypic features such as the ability to move by means of gliding, to ferment D-glucose, to produce oxidase and to form acids from carbohydrates, together with a lower DNA G + C content, strongly support the differentiation of strain KMM $6038^{\mathrm{T}}$ from Y. aromativorans. The sea urchin isolate is able to grow without $\mathrm{Na}^{+}$ ions or seawater and does not decompose agar or starch, in contrast to A. lectus KMM $3902^{\mathrm{T}}$. Although KMM $6038^{\mathrm{T}}$ is related most closely to strains of $A$. lectus, with $16 \mathrm{~S}$ rRNA gene sequence similarity of $93.8 \%$, the phylogenetic tree topology placed the strain studied more closely to Y. aromativorans $\mathrm{GW} 1-\mathrm{1}^{\mathrm{T}}$. In addition to the above-mentioned phylogenetic and phenotypic distinctiveness between KMM $6038^{\mathrm{T}}$ and its nearest neighbours, differences in cellular fatty acid composition clearly separate them.

Thus, the polyphasic data presented herein support the conclusion that the sea urchin bacterium studied could not be affiliated to any taxa currently included in the family Flavobacteriaceae. Consequently, we propose that KMM $6038^{\mathrm{T}}$ is the type strain of a novel species in a new genus, Mariniflexile gromovii gen. nov., sp. nov.

\section{Description of Mariniflexile gen. nov.}

Mariniflexile (Ma.ri.ni.fle'xi.le. L. adj. marinus, - $a$, - -um marine; L. part. adj. flexilis -e pliant, pliable, flexible; N.L. neut. n. Mariniflexile a flexible marine bacterium).

Cells are rod-shaped and motile by gliding. Gram-negative. Do not form endospores. Can ferment D-glucose. Produce non-diffusible orange pigments. Chemo-organotrophs. Cytochrome oxidase-, catalase- and alkaline phosphatasepositive. The predominant cellular fatty acids are straightchain saturated, branched-chain saturated and unsaturated fatty acids, iso- $\mathrm{C}_{15: 0}$, anteiso- $\mathrm{C}_{15: 0}$, iso- $\mathrm{C}_{15: 1}, \mathrm{C}_{15: 0}$, iso$\mathrm{C}_{17: 0} 3-\mathrm{OH}$ and summed feature 3 (comprising $\mathrm{C}_{16: 1} \omega 7$ and/or iso- $\mathrm{C}_{15: 0} 2-\mathrm{OH}$ ). The main lipoquinone is MK-6. As determined by $16 \mathrm{~S}$ rRNA gene sequence analysis, the genus is a member of the family Flavobacteriaceae, within the phylum Bacteroidetes. The type species is Mariniflexile gromovii.

\section{Description of Mariniflexile gromovii sp. nov.}

Mariniflexile gromovii (gro' mo.vi.i. N.L. gen. n. gromovii of Gromov, in honour of B. V. Gromov, the Russian aquatic and marine microbiologist). 
Table 1. Fatty acid composition of Mariniflexile gromovii gen. nov., sp. nov. KMM $6038^{\top}$ and its close relatives

Taxa: 1, M. gromovii KMM $6038^{\mathrm{T}}$; 2, Yeosuana aromativorans; 3, Algibacter lectus; 4, Formosa; 5, Gelidibacter; 6, Psychroserpens burtonensis; 7, Winogradskyella. Those fatty acids accounting for $<1 \%$ of the total for all taxa are not given. Data for reference taxa are taken from Bowman et al. (1997), Macián et al. (2002), Nedashkovskaya et al. (2004, 2005, 2006), Bowman \& Nichols (2005) and Kwon et al. (2006).

\begin{tabular}{|c|c|c|c|c|c|c|c|}
\hline Fatty acid & 1 & 2 & 3 & 4 & 5 & 6 & 7 \\
\hline iso- $\mathrm{C}_{14: 0}$ & & & & & & & $1 \cdot 4-4 \cdot 5$ \\
\hline iso- $\mathrm{C}_{14: 1}$ & & & & & & & $0-1 \cdot 4$ \\
\hline iso- $\mathrm{C}_{15: 0}$ & $15 \cdot 0$ & $21 \cdot 7$ & $12 \cdot 5$ & $12 \cdot 7-17 \cdot 2$ & $3 \cdot 4-8 \cdot 8$ & $10 \cdot 0$ & $6 \cdot 7-25 \cdot 6$ \\
\hline anteiso- $\mathrm{C}_{15: 0}$ & $5 \cdot 4$ & $14 \cdot 9$ & $7 \cdot 2$ & $1 \cdot 6-4 \cdot 7$ & $10 \cdot 5-17 \cdot 7$ & $10 \cdot 4$ & $4 \cdot 9-15 \cdot 9$ \\
\hline iso- $\mathrm{C}_{15: 1}$ & $16 \cdot 9$ & $14 \cdot 8$ & $13 \cdot 4$ & $6 \cdot 5-11 \cdot 4$ & $5 \cdot 3-11 \cdot 4$ & $14 \cdot 1$ & $8 \cdot 1-11 \cdot 4$ \\
\hline anteiso- $\mathrm{C}_{15: 1}$ & $1 \cdot 6$ & & & $0-1 \cdot 0$ & $11 \cdot 8-16 \cdot 6$ & $8 \cdot 4$ & $1 \cdot 4-6 \cdot 3$ \\
\hline $\mathrm{C}_{15: 0}$ & $13 \cdot 8$ & $5 \cdot 3$ & $13 \cdot 4$ & $8 \cdot 7-15 \cdot 5$ & $2 \cdot 4-5 \cdot 3$ & $10 \cdot 1$ & $1 \cdot 2-7 \cdot 9$ \\
\hline $\mathrm{C}_{15: 1}$ & $3 \cdot 1$ & & $10 \cdot 9$ & $6-11 \cdot 8$ & $2 \cdot 7-4 \cdot 2$ & $17 \cdot 5$ & $0-6 \cdot 5$ \\
\hline iso- $\mathrm{C}_{16: 0}$ & $1 \cdot 0$ & & & $1 \cdot 1-2 \cdot 1$ & $1 \cdot 4-4 \cdot 4$ & & $0 \cdot 8-5 \cdot 7$ \\
\hline iso- $\mathrm{C}_{16: 1}$ & $1 \cdot 5$ & & & $0-2 \cdot 5$ & $1 \cdot 4-10 \cdot 3$ & $9 \cdot 1$ & $2 \cdot 7-4 \cdot 7$ \\
\hline$C_{16: 0}$ 10-methyl & & $4 \cdot 7$ & & $1 \cdot 1-1 \cdot 6$ & & & $0-6 \cdot 3$ \\
\hline$C_{16: 0}$ & $1 \cdot 4$ & & & & & & \\
\hline $\mathrm{C}_{16: 1} \omega 5 c$ & & & & & & $6 \cdot 9$ & \\
\hline $\mathrm{C}_{16: 1} \omega 7 /$ iso- $\mathrm{C}_{15: 0} 2-\mathrm{OH}$ & $8 \cdot 4$ & $10 \cdot 9 /-$ & & $5 \cdot 9-15 \cdot 8$ & $7 \cdot 4 /-$ & & $4 \cdot 2-6 \cdot 1$ \\
\hline iso- $\mathrm{C}_{17: 1}$ & & & & $0-1 \cdot 4$ & & $1 \cdot 5$ & $0 \cdot 6-1 \cdot 1$ \\
\hline anteiso- $\mathrm{C}_{17: 1}$ & & & & & $1 \cdot 9-3 \cdot 4$ & & $0-2 \cdot 3$ \\
\hline anteiso- $\mathrm{C}_{17: 0}$ & & $4 \cdot 2$ & & & & & \\
\hline $\mathrm{C}_{17: 0}$ cyclo & & & & & & & $0-2 \cdot 4$ \\
\hline $\mathrm{C}_{17: 1}$ & $1 \cdot 1$ & & & $0-3 \cdot 5$ & $3 \cdot 7$ & $2 \cdot 7$ & $0 \cdot 9-1 \cdot 9$ \\
\hline iso- $\mathrm{C}_{14: 0} 3-\mathrm{OH}$ & & & & & & & $0 \cdot 9-1 \cdot 6$ \\
\hline $\mathrm{C}_{15: 0} 2-\mathrm{OH}$ & $1 \cdot 4$ & & & $1 \cdot 5-1 \cdot 8$ & & & $1 \cdot 0-3 \cdot 3$ \\
\hline iso- $\mathrm{C}_{15: 0} 3-\mathrm{OH}$ & $4 \cdot 3$ & & $9 \cdot 4$ & $6 \cdot 7-10 \cdot 5$ & $2 \cdot 2-6 \cdot 2$ & & $2 \cdot 6-11 \cdot 9$ \\
\hline $\mathrm{C}_{15: 0} 3-\mathrm{OH}$ & $1 \cdot 6$ & & & $2 \cdot 3-4 \cdot 0$ & & & $0-2 \cdot 5$ \\
\hline iso- $\mathrm{C}_{16: 0} 3-\mathrm{OH}$ & $2 \cdot 5$ & & & $3 \cdot 1-8 \cdot 9$ & $4 \cdot 1-12 \cdot 2$ & & $3 \cdot 2-18 \cdot 1$ \\
\hline $\mathrm{C}_{16: 0} 3-\mathrm{OH}$ & $1 \cdot 1$ & & & $0-2 \cdot 1$ & & & $0-1 \cdot 0$ \\
\hline iso- $\mathrm{C}_{17: 0} 3-\mathrm{OH}$ & $8 \cdot 9$ & & $9 \cdot 1$ & $8 \cdot 5-10 \cdot 7$ & $0-3 \cdot 1$ & & $5 \cdot 4-7 \cdot 3$ \\
\hline $\mathrm{C}_{17: 0} 2-\mathrm{OH}$ & & & & $0-1 \cdot 5$ & & & $0 \cdot 8-5 \cdot 2$ \\
\hline
\end{tabular}

In addition to characteristics given for the genus, cells range from 0.4 to $0.5 \mu \mathrm{m}$ in width and from 2 to $3 \mu \mathrm{m}$ in length. Colonies are circular, $2-3 \mathrm{~mm}$ in diameter, convex, shiny, orange and translucent on marine agar. Does not require $\mathrm{Na}^{+}$ions for growth. Growth occurs at $4-37^{\circ} \mathrm{C}$. Optimal temperature for growth is $23-25^{\circ} \mathrm{C}$. Growth occurs with 0-6\% NaCl. Decomposes gelatin. Does not hydrolyse agar, casein, starch, Tweens 20, 40 or 80 , urea, cellulose (CMcellulose and filter paper), chitin or DNA. Forms acid from L-fucose and DL-xylose, but not from L-arabinose, D-cellobiose, D-galactose, D-glucose, D-maltose, sucrose, D-lactose, D-melibiose, L-raffinose, glycerol, inositol or mannitol. Oxidizes L-rhamnose and $N$-acetylglucosamine. Utilizes D-lactose, D-mannose and sucrose, but not L-arabinose, adonitol, dulcitol, mannitol, inositol, sorbitol, malonate or citrate. Nitrate is not reduced. Indole, $\mathrm{H}_{2} \mathrm{~S}$ and acetoin (Voges-Proskauer reaction) production are negative.
Susceptible to ampicillin, carbenicillin, lincomycin and tetracycline. Resistant to benzylpenicillin, gentamicin, kanamycin, neomycin, oleandomycin, polymyxin B and streptomycin. Cellular fatty acids accounting for more than $1 \cdot 0 \%$ of the total are iso- $\mathrm{C}_{15: 1}(16 \cdot 9 \%)$, anteiso- $\mathrm{C}_{15: 1}(1 \cdot 6 \%)$, iso- $\mathrm{C}_{15: 0}(15 \cdot 0 \%)$, anteiso- $\mathrm{C}_{15: 0}(5 \cdot 4 \%), \mathrm{C}_{15: 0}(13 \cdot 8 \%)$, $\mathrm{C}_{15: 1} \omega 6 c(3 \cdot 1 \%)$, iso- $\mathrm{C}_{15: 0} 3-\mathrm{OH}(4 \cdot 3 \%), \mathrm{C}_{15: 0} 2-\mathrm{OH}$ $(1 \cdot 4 \%), \mathrm{C}_{15: 0} 3-\mathrm{OH}(1 \cdot 6 \%)$, iso- $\mathrm{C}_{16: 1}(1 \cdot 5 \%)$, iso- $\mathrm{C}_{16: 0}$ $(1 \cdot 0 \%), \mathrm{C}_{16: 0}(1 \cdot 4 \%)$, iso- $\mathrm{C}_{16: 0} 3-\mathrm{OH}(2 \cdot 5 \%), \mathrm{C}_{16: 0} 3-\mathrm{OH}$ $(1 \cdot 1 \%), \mathrm{C}_{17: 1} \omega 6 c(1 \cdot 1 \%)$, iso- $\mathrm{C}_{17: 0} 3-\mathrm{OH}(8 \cdot 9 \%)$ and summed feature $3\left(8 \cdot 4 \%\right.$; comprising $\mathrm{C}_{16: 1} \omega 7$ and/or iso$\left.\mathrm{C}_{15: 0} 2-\mathrm{OH}\right)$. The $\mathrm{G}+\mathrm{C}$ content of the DNA is $35 \cdot 7 \mathrm{~mol} \%$.

The type strain, KMM $6038^{\mathrm{T}}$ (=KCTC $12570^{\mathrm{T}}=\mathrm{LMG}$ $22578^{\mathrm{T}}$ ), was isolated from the sea urchin Strongylocentrotus intermedius, collected in Troitsa Bay, East Sea (also known as the Sea of Japan). 
Table 2. Differential characteristics of Mariniflexile gromovii gen. nov., sp. nov. $\mathrm{KMM} 6038^{\top}$ and its close relatives within the family Flavobacteriaceae

Data are taken from Bowman et al. (1997), Macián et al. (2002), Bowman \& Nichols (2005), Kwon et al. (2006), Lau et al. (2005), Nedashkovskaya et al. $(2004,2005,2006)$ and this study. V, Variable. Strain KMM $6038^{\mathrm{T}}$ and all members of the genera shown are positive for catalase activity.

\begin{tabular}{|c|c|c|c|c|c|c|c|}
\hline Characteristic & $\begin{array}{c}\text { Strain KMM } \\
6038^{\mathrm{T}}\end{array}$ & Yeosuana & Algibacter & Formosa & Gelidibacter & Psychroserpens & Winogradskyella \\
\hline Fermentation of D-glucose & + & - & + & + & - & - & - \\
\hline Oxidase & + & - & + & + & - & - & + \\
\hline$\beta$-Galactosidase & + & + & + & $\mathrm{V}$ & $\mathrm{V}$ & $\mathrm{V}$ & - \\
\hline Salinity range for growth $(\%, v / v)$ & $0-6$ & $0 \cdot 5-3 \cdot 0$ & $1-6$ & $0-8$ & $0-8$ & $2 \cdot 4-8$ & $1-8$ \\
\hline $\begin{array}{l}\text { Requirement for } \mathrm{Ca}^{2+} \text { and } \mathrm{Mg}^{2+} \\
\text { for growth }\end{array}$ & - & + & - & - & - & - & - \\
\hline $\begin{array}{l}\text { Acid formation from carbohydrates } \\
\text { Hydrolysis of: }\end{array}$ & + & - & + & + & + & - & $\mathrm{v}$ \\
\hline Agar & - & - & + & $\mathrm{V}$ & - & - & $\mathrm{V}$ \\
\hline Casein & - & - & - & - & $\mathrm{V}$ & + & V \\
\hline
\end{tabular}

\section{Acknowledgements}

This research was supported by grants from the Russian Foundation for Basic Research no. 05-04-48211, Presidium of the Far Eastern Branch of the Russian Academy of Sciences no. 06-04-96067 and Presidium of the Russian Academy of Sciences 'Molecular and Cell Biology'. J. K. and K.S.B. acknowledge support from the KRIBB Research Initiative programme.

\section{References}

Bernardet, J.-F., Nakagawa, Y. \& Holmes, B. (2002). Proposal minimal standards for describing new taxa of the family Flavobacteriaceae and emended description of the family. Int J Syst Evol Microbiol 52, 1049-1070.

Bowman, J. P. \& Nichols, D. S. (2005). Novel members of the family Flavobacteriaceae from Antarctic maritime habitats including Subsaximicrobium wynnwilliamsii gen. nov., sp. nov., Subsaximicrobium saxinquilinus sp. nov., Subsaxibacter broadyi gen. nov., sp. nov., Lacinutrix copepodicola gen. nov., sp. nov., and novel species of the genera Bizionia, Gelidibacter and Gillisia. Int J Syst Evol Microbiol 55, 1471-1486.

Bowman, J. P., McCammon, S. A., Brown, J. L., Nichols, P. D. \& McMeekin, T. A. (1997). Psychroserpens burtonensis gen. nov., sp. nov., and Gelidibacter algens gen. nov., sp. nov., psychrophilic bacteria isolated from Antarctic lacustrine and sea ice habitats. Int J Syst Bacteriol 47, 670-677.

Felsenstein, J. (1993). PHYLIP - Phylogeny Inference Package, version 3.5c. Distributed by the author. Department of Genome Sciences, University of Washington, Seattle, USA.

Fitch, W. M. \& Margoliash, E. (1967). Construction of phylogenetic trees. Science 155, 279-284.

Han, S. K., Nedashkovskaya, O. I., Mikhailov, V. V., Kim, S. B. \& Bae, K. S. (2003). Salinibacterium amurskyense gen. nov., sp. nov., a novel genus of the family Microbacteriaceae from the marine environment. Int J Syst Evol Microbiol 53, 2061-2066.
Kimura, M. (1980). A simple method for estimating evolutionary rates of base substitutions through comparative studies of nucleotide sequences. J Mol Evol 16, 111-120.

Kwon, K. K., Lee, H.-S., Jung, H.-B., Kang, J.-H. \& Kim, S.-J. (2006), Yeosuana aromativorans gen. nov., sp. nov., a mesophilic marine bacterium belonging to the family Flavobacteriaceae, isolated from estuarine sediment of the South Sea, Korea. Int J Syst Evol Microbiol 56, 727-732.

Lau, S. C. K., Tsoi, M. M. Y., Li, X. \& 7 other authors (2005). Winogradskyella poriferorum sp. nov., a novel member of the family Flavobacteriaceae isolated from a sponge in the Bahamas. Int J Syst Evol Microbiol 55, 1589-1592.

Macián, M. C., Pujalte, M. J., Márquez, M. C., Ludwig, W., Ventosa, A., Garay, E. \& Schleifer, K. H. (2002). Gelidibacter mesophilus sp. nov., a novel marine bacterium in the family Flavobacteriaceae. Int J Syst Evol Microbiol 52, 1325-1329.

Marmur, J. (1961). A procedure for the isolation of deoxyribonucleic acid from microorganisms. J Mol Biol 3, 208-218.

Marmur, J. \& Doty, P. (1962). Determination of the base composition of deoxyribonucleic acid from its thermal denaturation temperature. J Mol Biol 5, 109-118.

Nedashkovskaya, O. I., Kim, S. B., Han, S. K. \& 7 other authors (2004). Algibacter lectus gen. nov., sp. nov., a novel member of the family Flavobacteriaceae isolated from green algae. Int J Syst Evol Microbiol 54, 1257-1261.

Nedashkovskaya, O. I., Kim, S. B., Han, S. K. \& 9 other authors (2005). Winogradskyella thalassocola gen. nov., sp. nov., Winogradskyella epiphytica sp. nov. and Winogradskyella eximia sp. nov., marine bacteria of the family Flavobacteriaceae. Int J Syst Evol Microbiol 55, 49-55.

Nedashkovskaya, O. I., Kim, S. B., Vancanneyt, M. \& 9 other authors (2006). Formosa agariphila sp. nov., a budding bacterium of the family Flavobacteriaceae isolated from marine environments, and emended description of the genus Formosa. Int J Syst Evol Microbiol 56, 161-167.

Saitou, N. \& Nei, M. (1987). The neighbor-joining method: a new method for reconstructing phylogenetic trees. Mol Biol Evol 4, 406-425. 